\title{
Review
}

\section{Catastrophe and redemption: The political thought of Giorgio Agamben}

\author{
Jessica Whyte \\ SUNY Press, New York, 2013, 215pp., ISBN13: 978-1438448541 \\ Contemporary Political Theory (2016) 15, e40-e43. doi:10.1057/cpt.2015.17; \\ published online 12 May 2015
}

What distinctively marks the era of globalization is that political problems challenge boundaries, shifting our attention to the exteriority of law and calling into question the very basis of democratic self-rule. It is unsurprising that in this global political context the thought of the Italian philosopher Giorgio Agamben, who relentlessly thinks at the limits of law, has captured the imagination of political theory. In particular his gloomy diagnosis of Western politics has exerted great influence across the disciplines. It is to the credit of Jessica Whyte that she avoids choosing either between a full-fledged adoption of Agamben's bleak diagnosis or an outright rejection of his narrative on the violence of Western democracy. Whyte concedes to Agamben that the past two centuries were and still are especially violent and horrific, but she does not share his belief that this is necessarily so. Agamben is the critical thinker who believes that the catastrophe of lawlessness and disorder is not something that sovereign violence can avert (as Schmitt claims), but that, instead, the catastrophe is already occurring because of this sovereign violence (as he learns from Benjamin). This does not imply, however, that his reflections are without hope. Whyte makes an important contribution to the literature on Agamben by drawing our attention to the redemptive moment in his work that expresses the hope that our time makes possible a new form of life (over which sovereign power no longer has any hold) and a new form of politics (that resists the annexation by law). Redemption, form-of-life, coming community, new use, potentiality and the ungovernable are all abbreviations for the Agambenian hope that something good arises upon the ashes of sovereignty, rule of law, liberal democracy, citizenship and human rights.

Whyte offers an impressive overview of Agamben's oeuvre as a whole, deploying a three-pronged strategy. She expounds the conceptual framework wherein Agamben demonstrates and interprets the crisis of democracy and the rule of law, moves on to identify the redemptive moment amidst the wreckage, to finish with taking a critical distance from Agamben's understanding of redemption. Although Whyte appreciates the redemptive moments in Agamben's work, she strongly disagrees with him that 
catastrophe leads to redemption. Against Agamben, she argues that the intensification of the danger that he sees as a precondition for redemption will only cause a chain of collisions of one catastrophe after the other. In addition, she argues that Agamben's account of redemption suffers from two major shortcomings. First, Agamben ignores that attention must be paid to the emancipatory potential of past political struggles if one wants to take seriously the possibility of a new politics and life that is to disrupt the violent dialectic of constituting and constituted power. This also has an important implication for Whyte's evaluation of Agamben's theory on sovereignty. According to him, sovereignty consists of the decision over life that always produces bare life vulnerable to violence, turning biopolitics inevitably into thanatopoilitics. The claim that Western politics since its Greek origin contains the nucleus of the murderous events of the twentieth century imposes a preordained trajectory on law and politics that ignores that things could have been otherwise. 'Rather than Auschwitz revealing the hidden logic of the west', Whyte argues, 'it was the outcome of the defeat of all those who fought for a dramatically different world' (p. 82). Present struggles against 'bloody forms of inclusion and exclusion' (p. 127) should reopen these past possibilities to their advantage. Second, just as Agamben fails to ask what it means to act politically, he fails to incorporate a critical analysis of capitalism. If anything, it has been capitalism and the reign of the free world market that has plunged a large part of humanity in the deplorable state of mere survival. Indeed, if we want to locate, say, the causes of corporate human rights violations and the inhuman working conditions in sweatshops, we should not just look for a sovereign decision on the lives of these modern slaves. We should also start looking down the supply chain of the goods and products we consume.

Catastrophe and Redemption considers Agamben's reflections on biopolitics and sovereignty form the perspective of the relation between life and law. Whyte meticulously shows how the inclusive exclusion of naked life in the Greek polis prefigures the figure of homo sacer in Roman law, which, in turn, is the anacrusis of bare life that is exposed to sovereign violence in modern democracies. Crucial to the latter stage is the triumph of human rights that has caused the ultimate politicization of life. If, with human rights, bare life becomes the very presupposition and foundation of sovereign power, then the sovereign decision concerning which life is worthy of legal protection and which life is deemed unworthy is no longer exceptional but a matter of everyday politics. Against the backdrop of the separation of naked life and human life, Agamben coins the notion of form-of-life in which it is never possible to isolate something like a bare life. Whyte identifies this as one of the redemptive moments. But she is quick to point out that Agamben, unlike Foucault, fails to see that biopolitics is intimately bound up with capitalism. Agamben instead offers an ontological account of biopolitics that is, Whyte argues, oblivious of the fact that ontology can never answer the need for political action. The theme of political action, which resonates with Honig's (2011) critique of Agamben, is taken up in Whyte's discussion of the state of exception. In teasing out the relation between 
politics and law, Whyte takes seriously Agamben's wish to rethink politics without clothing it with the garment of law. To rethink a non-juridical politics, Whyte muses that the state of exception is double-sided: the fact that in the state of exception the law is in force without applying not only opens to violence, but also delivers us to the pure potentiality of the law. The need for political action also informs Whyte's appropriation of Agamben's reflections on the ethical questions raised by Auschwitz. This functions somewhat like a warning: if we, as Agamben suggests with Heidegger, patiently await redemption by passively enduring the intensification of danger, we will not receive salvation, but only more sorrow and wretchedness will befall us. The warning is accompanied by the advice that we should have the courage to face the political resistance inside the death camps. Ignoring that human beings in the most terrible and inhuman situation were able to resist, generates 'a particularly limited picture of the possibilities for politics in the present' (p. 92).

With Melville's Bartleby, Whyte returns the theme of the potentiality of the law, raising the question: what does refusal do to law? Whyte argues that refusal starts to make sense in the context of the potentiality of the law. This is by far the most interesting chapter as it teases out the remarkable resemblance between the status of the law in the messianic age and the dreadful legal condition of our own time, and in the wake of that, the relation between potentiality and the state of exception. Whyte convincingly demonstrates that Agamben slightly displaces the meaning of the state of exception in which the law applies in no longer applying by pointing out that a law that no longer has application opens up the possibility of a world that cannot be made juridical. Whyte also draws some political implications from this. Taking potentiality seriously, she argues, defies a substantialist politics that is merely concerned with the representation of factual and national constituencies. That is, taking potentiality seriously allows a politics of potential beings in which we are always other than we are which, Whyte asserts, enables a repotentialization of the past. To illustrate this, Whyte refers us to the example - again topical today - of the Greek resistance in 2011 against the suffocating austerity measures imposed by the Troika. Whyte points out that the protestors against the Troika depicted the Greek president as a collaborator, linking him to the collaborators of Nazism. According to Whyte, the Greek protestors played out a different legacy of World War II, 'not the persistence of Auschwitz but a history of refusal and resistance' (p. 165).

Given Whyte's engagement with emancipatory political action, her book could have profited from a more explicit understanding of the relation between political philosophy and the world of politics. Whyte seems to assume a simple correspondence between theory and praxis, for example, when she turns to Israel to prove Agamben wrong with respect to his thinking about catastrophe and redemption. Israel, she argues, may well be the redemption for the Jews but is of course the catastrophe for the Palestinians. She thus assumes that the validity of thinking depends on adequately describing a social practice and determining political action. But, as Taylor (1999, p. 101) rightly argues, there is no simple correspondence 
between thinking and the world of politics. For example, the ontological lack of a firm ground for a collective identity to stand on might well require drawing boundaries, and hence exclusion, on a political level. A good theory is able to define and transform our self-understanding of the practices with which we are engaged, and therefore helps us to better understand what we are doing. All we can hope for is that this makes our actions less impatient, haphazard and contradictory (Taylor, 1999, pp. 109-111). Notwithstanding the fact that the relation between thinking and politics remains theoretically underexposed, Catastrophe and Redemption offers a good critical overview of Agamben's work.

\section{References}

Honig, B. (2011) Emergency Politics: Paradox, Law, Democracy. Princeton, NJ: Princeton University Press.

Taylor, C. (1999) Philosophy and the Human Sciences: Philosophical Papers 2. Cambridge: Cambridge University Press.

Nanda Oudejans

Tilburg University, Tilburg, 5000 LE, The Netherlands n.oudejans@tilburguniversity.edu 